\title{
Effect of humic acid, seaweed extract and essential oils as antioxidants on pre-and post-harvest quality of red radish plants
}

\begin{abstract}
This study was carried out to assess the effect of certain biomodulators, namely seaweed extract, humic acid, peppermint and thyme oils, on quality-related metabolites during both pre- and post-harvest of Red radish. For this purpose, plants were sprayed with tested biomodulators twice, 20 and 30 days after sowing, and chosen biochemical constituents affecting quality were estimated before harvest, and again in roots of harvested plants after storage in standard cold storage. In addition, to evaluate the involvement of each tested parameter in post-harvest quality of stored roots, a correlation matrix between biochemical constituents after storage and quality parameters of stored roots represented by weight loss and post-harvest decay percentage as well as stored root's dry matter percentage. Results indicated that the adopted biomodulators affected the metabolism of treated plants in a way that persisted after storage, hence positively affected roots post-storage quality attributes. Invariably, stored roots of biomodulators-treated plants contained higher concentrations from total anthocyanins, ascorbic acid, total phenols, nutrients concentration as well as flavonoids compared with those of control plants. Moreover, activity of both peroxidase and polyphenol oxidase was higher in stored roots of biomodulators-treated plants. In addition, all applied biomodulators decreased weight loss and post-harvest decay percentage, thus roots of biomodulators-treated plants contained higher dry matter compared with roots of untreated plants. The metabolic and physiological bases of biomodulators-induced quality parameters of roots after storage were discussed.
\end{abstract}

Keywords: seaweed extract, humic acid, peppermint oil and thyme oil, red radish, raphanus sativus, post-harvest quality
Volume 3 Issue 3 - 2019

\author{
Moheb T Sakr,' Heba M Ibrahim,' Aml E \\ ElAwady, ${ }^{2}$ Amira A AboELMakarem ${ }^{2}$ \\ 'Botany Department, Faculty of Agriculture, Mansoura \\ University, Egypt \\ ${ }^{2}$ Post harvest and handling vegetables Research, Department of \\ Horticulture Research Institute, Egypt
}

Correspondence: Amira A AboELMakarem, Post harvest and handling vegetables Research, Department of Horticulture Research Institute, Agriculture Research Center, Giza, Egypt, Tel 01009170150,Email katkota613@yahoo.com

Received: March 04, 2019 | Published: May 24, 2019

\section{Introduction}

Raphanus sativus L. is a root vegetable widely grown for its nutritional, culinary and medicinal uses that belongs to Brassicaceae. It grows in temperate climates at altitudes between 190 and 1240 $\mathrm{m}$. Its roots are thick and of various sizes, forms, and colors. Red Radish belongs to the variety radicular. The edible fleshy axis is derived from the hypocotyl and upper radicle tissues. Radish is widely used in salad preparations and contains a considerable amount of antioxidants, vitamin C, and health-promoting compounds such as glucosinolates and phenolic compounds. Various parts of the radish plant, including roots, seeds, and leaves, have been used for medicinal purposes. Its health-promoting properties have been attributed to polyphenolic compounds. R. sativus is popularly used to treat liver and respiratory illnesses, ${ }^{1}$ reduce cancer development ${ }^{2}$ and contains arange of digestive enzymes. ${ }^{3}$ A comprehensive review of the plants active constituents and its therapeutic properties could be found in the publication of Gutiérrez and Perez. ${ }^{4}$ Radish has also been used in naturopathic medicine as a laxative, stimulant, and digestive aid, as well as in the treatment of stomach disorders. ${ }^{5}$ Red radish cultivars are a potential source of natural colorants due to the presence of anthocyanins, which have high stability. Anthocyanins have wellknown health benefits, including the ability to scavenge free radicals, inhibit cancer and diabetes, prevent neuronal and cardiovascular diseases, and suppress inflammation. ${ }^{6}$ Great attention is being given to post-harvest quality of vegetables due to rising consumer awareness about diet-health connections. Quality parameters of stored vegetables are determined by both pre- and postharvest factors. ${ }^{7}$ So, it is assumed that manipulation of growth and metabolism of plants during preharvest stage may have significant impact on postharvest quality of their stored products.
Humic acid (HA) are the most significant constituents of organic matter in soils and have a relevant role in the cycling of many elements in the environment and in soil ecological functions. ${ }^{8}$ Foliar sprays of HA promote growth, increase yield and quality in a number of plant species. ${ }^{9}$ Moreover, humic acid influence respiration process, the amount of sugars, amino acids and nitrate metabolism. ${ }^{10}$ Nardia et al. ${ }^{11}$ characterized the effects of HA on physiology of higher plants. According to them, HA positively influencing the uptake of some nutrients, especially nitrate, may influence both respiration and photosynthesis, may display a hormone-like activity, and exhibit stimulatory effects on plant cell growth and development.

Seaweed products exhibit growth-stimulating activities, and the use of seaweed formulations as bio modulators in crop production is well established. Seaweed components such as macro- and microelement nutrients, amino acids, vitamins, cytokinins, auxins, and abscisic acid (ABA)-like growth substances affect cellular metabolism in treated plants leading to enhanced growth and crop yield. ${ }^{12}$ In addition, it has been reported that seaweed extract enhanced the plant's antioxidant defense system of wheat plants subjected to drought stress through elevating both the enzymatic and non-enzymatic components of the plant's antioxidant defense system. ${ }^{13}$

Essential oils are well known for their antioxidant and antimicrobial properties that prevent food degradation and alteration. ${ }^{14}$ They possess antimicrobial properties and prevent growth of bacteria, fungus and virus during storage and protect cells from senescence, thereby increase shelf life of vegetables. Thyme oil contains more than $40 \%$ phenolic constituents (thymol, carvacrol and caffic acid) which have strong antispectic effects. Essential oils chemical composition of Thymus vulgaris and Mentha piperita were identified by GC-MS 
where the most components of thyme were thymol (44.7\%), cymenin $(18.6 \%)$ and tripeneine $(16.5 \%)$ whereas menthol and menthone are the main components of peppermint oil. ${ }^{15}$ Application of $4 \%$ thyme and basil oils had a positive effect on broccoli seed germination, which was ascribed to their antioxidant and disinfecting effects. ${ }^{16}$

The objectives of the current investigation was to assess the effect of bio stimulators seaweed extract (SWE), humic acid (HA), thyme oil as well as peppermint oil on certain quality-related biochemical constituents during both pre- and post-harvest stages.

\section{Materials and methods}

Two field experiments were conducted during the two consecutive growing seasons of 2015 and 2016 at EL-Bramoon Farm, Mansoura city, Dakahlia Governorate. Seeds of Raphanus sativus L., (var. Cherry red) were secured from Vegetables Dept., Horticulture Research Institute, ARC, Egypt and planted on October 22th during both growing seasons. Soil samples at $30 \mathrm{~cm}$ depth were taken for estimating the experimental soils physical and chemical characteristics (Table 1) according to. ${ }^{17}$ The experimental design was randomized complete block design with three replicates. Each replicate contained three rows, six meters in length and $3 \mathrm{~m}$ in width, with the total experimental area of $162 \mathrm{~m} 2$. Within the row, the distance between plants was $20 \mathrm{~cm}$. Plants were sprayed twice, 20 and 30 days after sowing (DAS) onto foliage with solutions of Seaweed Ecklonia maxima extract (SWE,) at the rate of $4 \mathrm{ml} \mathrm{L}-1$, Humic acid (HA) at the rate of $30 \mathrm{ml} \mathrm{L}-1$, Peppermint oil (P.O) at the rate of $50 \mathrm{ml} \mathrm{L}-1$, and Thyme oil (T.O) at the rate of $50 \mathrm{ml} \mathrm{L}-1$. Control plants were sprayed with tap water. Tween 20 was added to sprayed solutions at the rate of $0.05 \%$ as a wetting agent. Seaweed extract and humic acid were obtained from Shoura Company, Egypt. Peppermint and thyme oils were obtained by hydro-distillation for 2-3 $\mathrm{h}$ in the Post-harvest Lab., Hort. Res. Station, Agric. Res. Cent., Egypt, using modified Clevenger apparatus according to Guenter. ${ }^{18}$ Samples were collected 40 DAS to determine the contents of anthocyanins, total phenols, total flavonoids, ascorbic acid, total carbohydrates, total free amino acids as well as the activity of Peroxidase and Polyphenol oxidase.

Anthocyanins were determined according to Chiriboga and Francis. ${ }^{19}$ Total phenols were measured calorimetrically at 650 $\mathrm{nm}$ using Folin-ciocalteu reagent according to Bray and Thorpe. ${ }^{20}$ Total flavonoids content was estimated calorimetrically at $510 \mathrm{~nm}$ as described by Heimler et al. ${ }^{21}$ Ascorbic acid was determined by the 2,6-Dichlorophenolindophenol dye procedure of Freed..$^{22}$ Total carbohydrates were determined using phenol sulphuric acid method according to Dubios et al. ${ }^{23}$ Total free amino acids were determined according to the procedure of Moore and stein. ${ }^{24}$ Peroxidase extraction and assay were performed according to the procedure of Maxwell and Bateman. ${ }^{25}$ Polyphenol oxidase (PPO) extraction and assay were performed according to Maria et al. ${ }^{26}$

Plants were uprooted 60 DAS and samples from roots (ten roots from each replicate) were packed in polyethylene bags and stored at controlled storage conditions $\left(5^{\circ} \mathrm{C}\right.$, relative humidity $\left.95 \%\right)$ for three months. Afterwards, postharvest quality and storage parameters represented by weight loss percentage, post-harvest decay percentage and dry matter percentage were estimated. Weight loss percentage (WLP \%) was estimated according to the following equation:

Table I Physical and chemical characteristics of the experimental soil average of the two growing seasons

\begin{tabular}{llllllll}
\hline Texture & Organic matter\% & Total carbon\% & Ec(ds m-I) & $\mathbf{p H}$ & $\mathbf{N} \%$ & $\mathbf{P} \%$ & $\mathbf{K} \%$ \\
\hline Clay & 1.8 & 1.82 & 0.75 & 8.65 & 0.19 & 0.015 & 0.14 \\
\hline
\end{tabular}

WLP\% $\%=[$ Initial $-($ Final Weight $/$ Initial Weight $)] \times 100$ (A.O.A.C, 2007) Post-harvest decay percentage (PDP \%) was estimated according to the formula: (Number of Decayed Fruits/ Number of Total Fruits) $\times 100 .{ }^{27}$ Dry matter percentage (DMP \%) was estimated as described by Lee. ${ }^{28}$ After drying in the oven at $60^{\circ} \mathrm{C}$ until weight stability, moisture percentage was calculated according to the equation:

Fresh weight of root before storage-Dry weight of root after storage)/Dry weight of root after storage $\times 100$; then dry matter $(\%)$ was estimated as (100 - \% moisture percentage).

\section{Statistical analysis}

Data were subjected to analysis of variance using GENSTATE software (version 11.1.0.1575). To compare differences between means, least significant differences (LSD) at $5 \%$ were calculated according to Gomez and Gomez. ${ }^{29}$

Correlation matrix between biochemical analysis after storage in refrigerator at $\left(5^{\circ} \mathrm{C} / \mathrm{Rh} 95 \%\right)$ and storage parameters at the 0.05 and 0.01 level (2-tailed) on PASWStatistics 18 software. The sign of the correlation coefficient determines whether the correlation is positive or negative. The magnitude of the correlation coefficient determines the strength of the correlation subjected by Evans ${ }^{30}$ suggests absolute r-value $\{0.00-0.19$ (very weak), 0.20-0.39 (weak), 0.40-0.59 (moderate), 0.60-0.79 (strong) and 0.80-1.0 (very strong)\}.

\section{Results}

\section{Effect of bio modulators on biochemical constituents during pre- and post-harvest stages}

\section{Total anthocyanin and ascorbic acid}

All applied bio modulators increased total anthocyanin's concentration in the roots either pre- or post-harvest compared to control (Table 2). The highest anthocyanins concentrations were obtained in response to treatment with thymus oil followed by humic acid in preharvest stage. In roots that stored in the specified storage experimental conditions, total anthocyanin concentration was decreased, either in biomodulators-treated or untreated plants compared with before storage. However, in post-harvest stage anthocyanins concentrations were highest in response to the treatment with peppermint oil followed by seaweed extract i.e. peppermint oil and seaweed extract caused the least decline in anthocyanins concentration in stored roots, in order. Data presented in Table 2 show that ascorbic acid concentration in pre-stored roots was increased in response to thyme oil and seaweed extract, though the increase was insignificant in case of seaweed extract treatment. On the other hand, humic acid and peppermint oil did not affect ascorbic acid concentration in the roots before storage. In stored roots, ascorbic acid concentration was decreased either in bio modulators-treated or untreated plants. However, the magnitude of decline was lower in roots of bio modulators-treated plants. So, 
after storage, ascorbic acid concentration in roots was significantly higher in all biomodulators treatments compared with control .The lowest loss percentage was recorded in response to peppermint oil (29.7\%) followed by humic acid (31.7\%).

\section{Total phenols and flavonoids}

All applied bio modulators increased total flavonoids in roots during both pre-and post-harvest stages as well as total phenols only during post-harvest stage (Table 3). The only bio modulator that increased total phenols in the roots before storage was Peppermint oil. Both total flavonoids and phenols were decreased after storage, but the decrease was lower in case of total flavonoids. The lowest decrease in total phenols was recorded in response to Peppermint oil whereas the least decrease in total flavonoids was recorded in response to thyme oil treatment.

Table 2 Effect of applied bio modulators on total anthocyanin's and ascorbic acid content (mgg' F.W.) in roots of Raphanus sativus L, plants before and after storage

\begin{tabular}{lllllll}
\hline \multirow{2}{*}{ Parameters } & \multicolumn{3}{l}{ Anthocyanins (mgg-I F.W.) } & \multicolumn{3}{l}{ Ascorbic acid (mgg-I F.W.) } \\
\cline { 2 - 7 } Treatments & Before & After & Total loss \% & Before & After & Total loss \% \\
\hline Seaweed extract & 6712 & 1753 & 55.52 & 24.13 & 13.97 & 42.11 \\
Humic acid & 8.51 & 743 & 68.86 & 1731 & 32711 & 13753 \\
Peppermint oil & 6700 & 2732 & 44.77 & 1730 & 32720 & 29.71 \\
Thyme oil & 6733 & 741 & 47737 & 15731 & 735 & 39.16 \\
Control & 5734 & 3722 & 57767 & 1723 & 7701 & 32756 \\
LSD at 0.05 & $174 I$ & 1707 & - & 4710 & 3731 & - \\
\hline
\end{tabular}

Table 3 Effect of applied bio modulators on total phenols and flavonoids (mgg-1 D.W) roots of Raphanus sativus plants before and after storage

\begin{tabular}{lllllll}
\hline \multirow{2}{*}{$\begin{array}{l}\text { Parameters } \\
\text { treatments }\end{array}$} & \multicolumn{3}{c}{ Total phenols (mg g-I F.W.) } & \multicolumn{3}{c}{ Total flavonoids (mgg-I F.W.) } \\
\cline { 2 - 7 } & Before & After & Total loss\% & Before & After & Total loss\% \\
\hline Seaweed extract & 32727 & 30716 & 16.63 & 1711 & 0.29 & 12.12 \\
Humic acid & 31723 & 31756 & 19.61 & 1721 & 1713 & 12.5 \\
Peppermint oil & 32763 & 30723 & 16.16 & 1717 & 1712 & 12.82 \\
Thyme oil & 31711 & 31720 & 19.85 & 1725 & 1722 & 6.38 \\
Control & 12.5 & 9.51 & 23.92 & 0.31 & 0.26 & 16.13 \\
LSD at 0.05 & 711 & 3710 & - & 1713 & 1711 & - \\
\hline
\end{tabular}

\section{Total carbohydrates and total free amino acids}

Generally, total carbohydrates concentration in roots before storage was increased in response to bio modulators treatments, though the increase was insignificant (Table 4). In addition, roots of bio modulators-treated plants after storage contained higher concentrations of total carbohydrates compared with control roots, though the differences did not reach the significance level. In all treatments, total carbohydrates concentrations were decreased after storage, with the least decrease in response to seaweed extract followed by Peppermint oil treatment.

Total free amino acids concentrations in roots treated with all bio modulators before storage were not significantly different than that in control roots (Table 4). On the other hand, roots of bio modulators-treated plants after storage contained significantly higher concentrations of total free amino acids compared with control Storage caused a decrease in total free amino acids concentrations in roots of bio modulators-treated as well as control plants. In stored roots of seaweed extract-treated plants, the decrease in concentration of total free amino acids was the least, followed by thyme oil.

\section{Concentration of potassium and sulphur}

Roots of biomodulators-treated plants either before or after storage contained higher concentrations of both potassium (K) and sulphur (S) compared with control roots (Table 5). However, the recorded increase in $\mathrm{S}$ concentration before storage was insignificant in response to all biomodulators treatments. In roots of biomodulators-treated as well as control plants, concentrations of both potassium $\mathrm{K}$ and $\mathrm{S}$ were decreased after storage. The decrease was of the least magnitude in response to seaweed extract treatment in case of $\mathrm{K}$ and in response to peppermint oil in case of $\mathrm{S}$.

\section{Activity of peroxidase and polyphenol oxidase}

In roots of biomodulators-treated plants, the activity of peroxidase (POD) was increased either before or after storage compared with that in roots of control plants. A similar trend in the activity of polyphenol oxidase (PPO) was recorded in roots after storage. On the other hand, before storage, PPO activity in roots was increased in response to seaweed extract and peppermint oil treatments whereas decreased in response to humic acid and thyme oil treatments. Storage affected the activity of both POD and PPO, but in different manner. Where 
POD activity was decreased after storage, PPO activity was increased (Figure 1). The least decrease in POD activity was recorded in response to thyme oil treatment, whereas the highest increase in PPO activity was achieved in response to humic acid treatment.

Table 4 Effect of applied biomodulators on total carbohydrates ( $\left.\mathrm{mgg}^{-1} \mathrm{D} . \mathrm{W}.\right)$ and free amino acids (mg/l00 g D.W.) in dried roots of Raphanus sativus plants before and after storage

\begin{tabular}{|c|c|c|c|c|c|c|}
\hline \multirow{2}{*}{$\begin{array}{l}\text { Parameters } \\
\text { Treatments }\end{array}$} & \multicolumn{3}{|c|}{ Total carbohydrates (mgg-I D.W.) } & \multicolumn{3}{|c|}{ Total free amino acid ( $\mathrm{mg} / 100 \mathrm{~g}$ D.W.) } \\
\hline & Before & After & Total loss\% & Before & After & Total loss\% \\
\hline Seaweed extract & 305731 & $3|276|$ & 17.8 & 12.09 & 5.64 & 53.35 \\
\hline Humic acid & 305711 & 90.83 & 28.5 & 12.49 & 2777 & 60.05 \\
\hline Peppermint oil & 304741 & 313770 & 19.49 & 31734 & 2712 & 67.99 \\
\hline Thyme oil & 330730 & 62711 & 27.46 & 30744 & 3701 & 58.93 \\
\hline Control & $33|77|$ & 57711 & 28.76 & $307 \mid 1$ & 1711 & 72.57 \\
\hline LSD at 0.05 & 742 & 3752 & - & $|75|$ & 1727 & - \\
\hline
\end{tabular}

Table 5 Effect of applied biomodulators on potassium concentration ( $\mathrm{mgg}^{-1}$ D.W.) and Sulphur percentage in dried roots of Raphanus sativus plants before and after storage

\begin{tabular}{|c|c|c|c|c|c|c|}
\hline \multirow{2}{*}{$\begin{array}{l}\text { Parameters } \\
\text { Treatments }\end{array}$} & \multicolumn{4}{|c|}{ Potassium (mg g-I D.W.) } & \multicolumn{2}{|c|}{ Sulfur (\%) } \\
\hline & Before & After & Total loss\% & Before & After & Total loss\% \\
\hline Seaweed extract & 30726 & 33711 & 11.86 & 1.43 & 0.93 & 34.97 \\
\hline Humic acid & 31711 & 31711 & 1716 & 1.2 & 0.9 & 25 \\
\hline Peppermint oil & 31742 & 31717 & 26.03 & 3731 & 3733 & 23.33 \\
\hline Thyme oil & 31704 & 31715 & 24.06 & 3707 & 3713 & 21.71 \\
\hline Control & 12.37 & 7711 & 5702 & 3731 & 1731 & 54.55 \\
\hline LSD at 0.05 & 1733 & 1753 & - & 1726 & 1713 & - \\
\hline
\end{tabular}

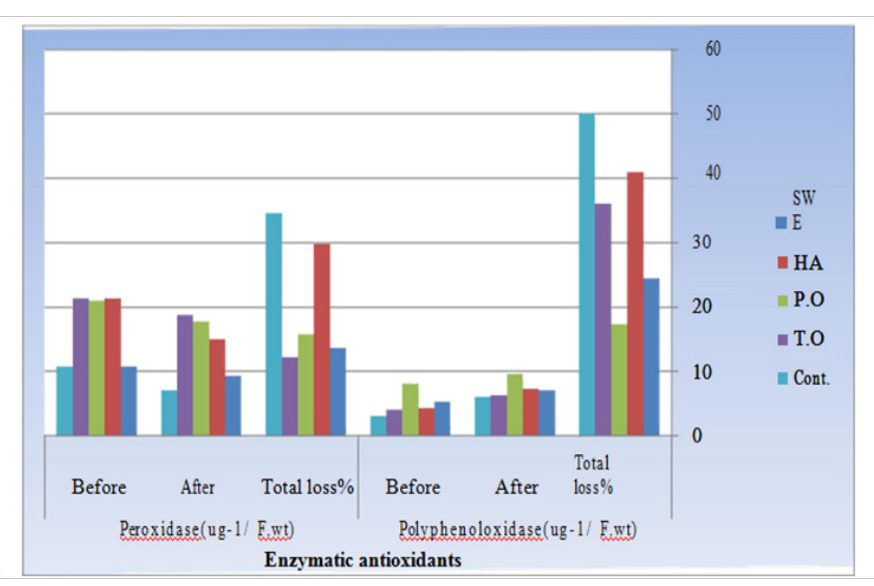

Figure I Effect of applied bio modulators on the activity (Ug-I F.W.) of Peroxidase (POD) and Polyphenoloxidase (PPO) in roots of Raphanus sativus plants before and after storage.

\section{Effect of biomodulators on post-harvest quality parameters of stored roots}

After two months-storage, stored roots had visible decay symptoms manifested by rotting, water stains and unusual smell due to growth of bacteria and fungus on roots. However, quality parameters of stored roots were differed between biomodulators treatments and control. All applied biomodulators decreased weight loss and post-harvest decay percentages hence, roots of biomodulators-treated plants contained higher dry matter compared with the roots of untreated plants. Weight loss as well as post-harvest decay percentage was minimum in response to peppermint treatment, followed by thyme oil treatment. Nevertheless, dry matter percentage in stored roots was highest due to seaweed extract followed by humic acid treatments (Figure 2).

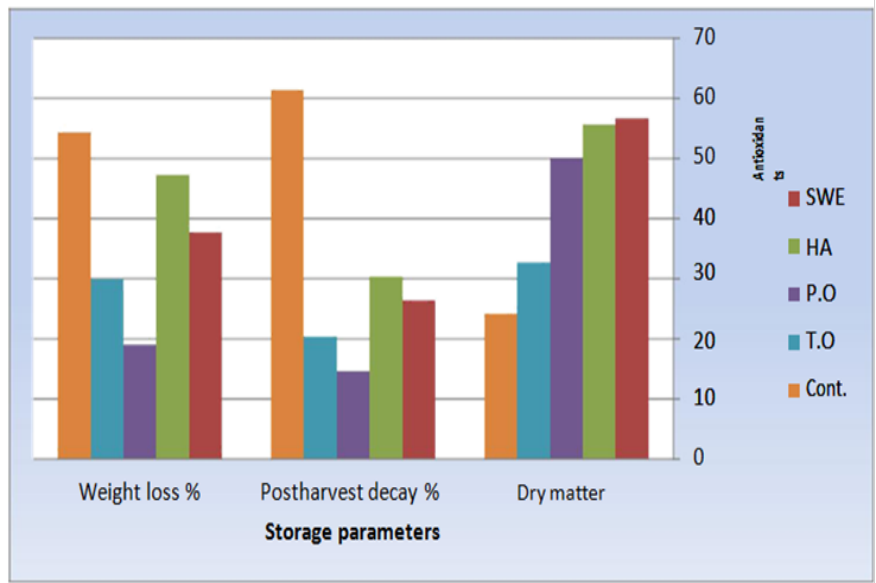

Figure 2 Quality parameters of stored roots of Raphanus sativus plants after storage for three months in refrigerator at $5^{\circ} \mathrm{C}$ and $95 \%$ relative humidity as affected by biomodulators treatments. 


\section{Pearson's correlation matrix between roots biochemical analyses after storage and their post- harvest quality parameters}

In Table 6 showed the output of Pearson's correlation matrix between biochemical analysis after storage in refrigerator at $\left(5^{\circ} \mathrm{C} /\right.$ $\mathrm{Rh} 95 \%$ ) for three months and storage parameters of radish plants in first season 2015. Dry matter and post-harvest decay showed very strong significant negative as follow $(-0.90$ and -0.99$)$ respectively relationship with sulfur concentration at the 0.05 and 0.01 level. Total anthocyanin revealed very strong significant positive as follow (0.98 and 0.92) relationship with total phenols and carbohydrates at the 0.05 and 0.01 level. Ascorbic acid, total phenols, flavonoids and anthocyanin recorded very strong significant positive as follow $(0.95$, $0.97,0.89$ and 0.91 ) respectively relationship with total flavonoids, carbohydrates, potassium concentration and peroxidase enzyme at the 0.05 and 0.01 level.

Table 6 Pearson's correlation matrix between roots biochemical analyses after storage and their post-harvest quality parameters

\begin{tabular}{|c|c|c|c|c|c|c|c|c|c|c|c|c|c|}
\hline DM\% & DM \% & PDP \% & WLP \% & T.A & ASA & T.P & T.F & T.C & T.A & K & $\mathbf{S}$ & POD & PPO \\
\hline PDP\% & 0.88 & & & & & & & & & & & & \\
\hline WLP\% & -0.3 & -0.61 & & & & & & & & & & & \\
\hline T.A & -0.83 & -0.83 & 0.72 & & & & & & & & & & \\
\hline ASA & -0.57 & -0.69 & 0 & 0.21 & & & & & & & & & \\
\hline T. P & -0.73 & -0.77 & 0.79 & $0.98^{* *}$ & 0.11 & & & & & & & & \\
\hline T. F & -0.52 & -0.66 & -0.02 & 0.14 & $0.95 *$ & 0.02 & & & & & & & \\
\hline T.C & -0.57 & -0.66 & 0.85 & $0.92 *$ & 0 & $0.97 * *$ & -0.12 & & & & & & \\
\hline T.A & -0.35 & -0.7 & 0.66 & 0.46 & 0.62 & 0.51 & 0.47 & 0.56 & & & & & \\
\hline $\mathrm{K}$ & -0.48 & -0.72 & 0.78 & 0.71 & 0.38 & 0.77 & 0.19 & 0.83 & $0.91 *$ & & & & \\
\hline$S$ & $-0.90 *$ & $-0.99 * *$ & 0.61 & 0.86 & 0.63 & 0.79 & 0.62 & 0.67 & 0.63 & 0.67 & & & \\
\hline POD & -0.74 & -0.81 & 0.2 & 0.45 & 0.78 & 0.31 & $0.89 *$ & 0.13 & 0.35 & 0.21 & 0.82 & & \\
\hline PPO & -0.72 & -0.64 & 0.57 & 0.86 & -0.04 & 0.81 & 0.05 & 0.7 & 0.05 & 0.29 & 0.71 & 0.49 & \\
\hline
\end{tabular}

*Correlation is significant at the 0.05 level (2-tailed).

** Correlation is significant at the 0.01 level $(2$ tailed)

DM, dry matter; PDP, post-harvest decay; WLP, weight loss; TA, total anthocyanin's; AsA, TP, total phenols; ASA, ascorbic acid; TF, total flavonoids; TC, total carbohydrates; TA, total amino acids; K, potassium; S, sulphur; POD, peroxidase; PPO, polyphenoloxidase

\section{Discussion}

\section{Cold storage and post-harvest quality of plant products}

Senescence is the most important internal factor that causes damage to vegetables whereas low temperature is the best way to delay post-harvest deterioration of fruits and vegetables. In this context, Bayomi ${ }^{31}$ concluded that the higher post-harvest decay percentage in late harvesting stage of fruits is due to higher rate of respiration, more skin permeability for water loss and high susceptibility to decay. Dry matter acts an index to evaluate the fruit quality due to endure prolonged storage..$^{32}$ Generally, low temperature can maintain organic matter and vitamins levels in short and long term storage because most enzyme activities decrease and the expression of many genes inhibited during cold storage. Low temperature markedly delays senescence of broccoli during storage. ${ }^{33}$ In addition, Shen et al. ${ }^{34}$ reported that refrigeration can reduce deterioration and extend shelf life of fresh fruits by delaying the metabolic processes. Dry matter production represents a balance between photosynthesis and respiration. Respiration rate, which has long been used to measure metabolic process in stored produce,,$^{35,36}$ is governed by water availability, temperature, $\mathrm{O} 2$ concentration, microbial contamination, mechanical damage, among other factors. Porter et al. ${ }^{37}$ reported that respiration rate of chinese cabbage was higher at $20^{\circ} \mathrm{C}$ than at lower temperatures.

\section{Effect of essential oils on post-harvest quality parameters}

Synthetic chemicals are commonly used in the control diseases of stored plant products however; these chemicals may cause toxic residues in treated plants. ${ }^{38}$ Alternatively, the use of natural products like herbal extracts and essential oils can reduce harm to public health and preserve the environment from pollution. These ecofriendly plant-derived products generally possess a broad spectrum of activity against several pathogens and pests. ${ }^{39}$ Essential oils are natural complex compounds with a strong smell and produced as secondary metabolites in aromatic plants. In nature, essential oils acts as antibacterial, antivirus, antifungal and insecticides. It contains compositions of terpenes, sesquiterpenes, aldehydes, ketones and phenolic compounds. ${ }^{40}$ The main chemical components of thyme oil are thymol, carvacrol, $\alpha$ - pinene, $\beta$-pinene, borneal, linalool, $\beta$-simine and camphene. ${ }^{41}$ The composition of volatile oil of $\mathrm{M}$. piperita is menthol, monoterpene and methofuran. ${ }^{42}$ These constituents act as inhibitor for pathogens growth during cold storage and reduce senescence in treated plants.

In the current investigation, thyme as well as peppermint oil decreased weight loss and post-harvest decay percentages hence, preserved roots dry matter during cold storage (Figure 2). These findings are in harmony with those of previous studies. ${ }^{43-48}$ 
Biomodulators-induced enzymatic, non-enzymatic antioxidants and their relationship with post-harvest quality:

Antioxidants play an important role in scavenging reactive oxygen species (ROS) that appear during storage-related senescence of vegetables. ${ }^{49}$ Antioxidant capacity is directly correlated with phenolic compounds..$^{50,51}$ Therefore, plants with enhanced levels of antioxidants can resist oxidative damage..$^{52}$ The results of the present investigation revealed that generally, the applied biomodulators diminished the decline in concentrations of anthocyanins, ascorbic acid, phenols and flavonoids as well as in the activity of the antioxidant enzyme, peroxidase. This implies that stored roots of biomodulators-treated plants contained higher levels of antioxidants compared with roots of untreated plants. Similar conclusions were made based on the results of previous studies. ${ }^{53-57}$ How elevated levels from these constituents preserve roots quality during storage could be discussed as follows:

\section{Anthocyanins}

Anthocyanin's belong to flavonoids group and located in a cell vacuole.$^{58}$ It plays important role as an antioxidant. The anthocyanin pigment inhibits active oxygen radicals formed by exposure to stress conditions that occur during storage periods due to pathological injures i.e., enzymatic browning, molds and water stains on fruits. The results of some in vitro experiments indicated that anthocyanin pigments scavenge superoxide, active oxygen radicals ${ }^{59}$ and hydrogen peroxide..$^{60}$ On the other hand, anthocyanin pigment is affected by the amount of sugar due to a lower water activity Hubbermann et al. ${ }^{61}$ Lopez-Andreu et al. ${ }^{62}$ reported that anthocyanins concentration was decreased at the end of the cold storage period, which imply that they are consumed in scavenging storage-related ROS.

\section{Ascorbic acid}

Ascorbic acid is a major component of the plant defense system ${ }^{63}$ that protect biological processes of the plant from ROS generated during biotic and abiotic stresses.$^{64}$ In addition, it has a pivotal role in eliminating $\mathrm{H} 2 \mathrm{O} 2$ through the glutathione-ascorbate cycle that operates in the cytosol, mitochondria, plastids and peroxisomes where it involves ascorbate, glutathione, NADPH and the enzymes linking these metabolites during long term storage. Since glutathione, ascorbate and NADPH are present in high concentrations in plant cells it is assumed that the glutathione-ascorbate cycle plays a key role for $\mathrm{H}_{2} \mathrm{O}_{2}$ detoxification. Peroxidases also contribute to $\mathrm{H}_{2} \mathrm{O}_{2}$ removal in plants. The destruction of ascorbic acid is one of the most serious problems facing plants under stress conditions, whether in the soil or when storing in the short or long term. ${ }^{65}$ The oxidized form of ascorbic acid is more prone to decomposition during storage in low temperature. Ascorbic acid decreases during storage due to its consumption in the ROS-detoxification process especially at temperature above $0^{\circ} \mathrm{C}^{66}$ through oxidation in the presence of ascorbate oxidase enzyme, and changes back to its active form. ${ }^{67}$ The antioxidant role of ascorbic acid in mitigating stress-related metabolic abnormalities was evident from the results of other studies. ${ }^{43,45,53,68,69}$

\section{Phenolic compounds}

Post-harvest stresses e.g. mechanical injuries and others during storage led to enzymes activity that responsible for phenolic compounds deterioration. ${ }^{70}$ Phenolic compounds and enzymes do not interact with each other because of their different locations within cells consequently; shelf life of vegetables and fruits is increased. However, when membranes are damaged, destruction and oxidation of phenolic compounds are initiated, causing breakdown of defense line in the cell against free radicals..$^{70,71}$ Similar conclusions were made by Wang et al. ${ }^{53}$ and Abd EL-Wahab. ${ }^{47}$ Flavonoids are the most important group of phenolic compounds in plants ${ }^{49}$ that assist in scavenging free radicals and inhibiting oxidative stress, thereby decreasing cell membrane deterioration during long storage ${ }^{51}$ which low temperature could decrease the membrane lipid degradation and POD activity as a result, it can slow down flavonoids oxidation. These results are in agreement with those obtained by Dupont et al. ${ }^{72}$ on lettuce, Yuan et al. ${ }^{73}$ on broccoli plants and Geransayeh et al ${ }^{46}$ on strawberry fruits.

\section{Total carbohydrates}

Carbohydrates are among the most prevalent organic compounds and represent the most important sources of energy in the plant. This energy from the sun was obtained in photosynthesis process (anabolism) and it is released through respiration (catabolism). Finally, the carbohydrates serve as the starting compounds for the biogenesis of many other cell constituents. Total carbohydrates represent the production of both sugars and starch within the cell. This study showed increased photosynthesis and increased plant growth rate with adding HA and SWE treatments in the open field led to an increase in the rate of carbohydrate content. These results are in harmony with those recorded by Bakry et al. ${ }^{74}$ on two wheat cultivars, Ameri and Tehranifar ${ }^{75}$ on Fragaria ananasa L. Antioxidants applied in the field experiment led to a significant increase in storage of fruits due to increased carbohydrates anabolism process within plant cells. Accordingly, the rate of broccoli plants respiration effect on carbohydrate levels when storage in cold temperature at $5^{\circ} \mathrm{C}$. These results are in agreement with those reported by ${ }^{76}$ on Vigna radiate plants that also supported by Wills et al. ${ }^{77}$ reported that decrease in fruit metabolic activities results in a decrease in fruit water loss and carbohydrates depletion rate and for this reason senescence process delayed in fruits in short-term storage at specific temperature.

\section{Total free amino acids}

The amino acid pool is only a small portion of the total dissolved organic nitrogen pool, which generally contains less than $10 \%$ free amino acids in temperate ecosystems. ${ }^{78,79}$ So, several studies have shown that plants can up take $\mathrm{N}$ in forms of amino acids without relying on microbial mineralization. ${ }^{80}$ Amino acids of algae such as amids, cyanogenic, glycosides, purines, porphyrins and cytokinins have been studied by ${ }^{81,82}$ which are involved in the processes of bio-synthesis of protein that have directly or indirectly affect the physiological processes within the plant. The present study supported results of ${ }^{83}$ found the free amino acid concentration were also more in Brassica nigra treated with $10 \%$ SWE of P. teriastromatica and S. linearifolium, ${ }^{84}$ reported the free amino acids may be act as protective agents of membrane that protect the cells from biotic and a biotic stress pre or postharvest and Bakry et al. ${ }^{74}$ on two wheat cultivars. The content of amino acid components in dried roots of radish plants changed with different storage intervals and temperature. The results were showed significantly increase with peppermint oil compared with control plants. Accordingly, application of P.O reduced total amino acids degradation in the roots of radish plants. In general, the percentage of total amino acids decreased due to low respiratory rate and enzymatic activity Pareek et al. ${ }^{85}$

\section{Nutrients concentration (sulfur and potassium)}

Sulfur (S) is fourth essential macro element for plant nutrition 
after nitrogen, phosphorus and potassium. Plants can absorb sulfates and convert them into essential amino acids, which are involved in metabolism. S plays an important role in the growth and development of higher plants Osman and Rady ${ }^{86} \mathrm{~S}$ deficiency affects on synthesis of chlorophyll, nitrogen concentration in leaves and photosynthetic enzymes Lunde et al.$^{87}$ led to reduce the quality and quantity of yield. ${ }^{86,88}$ Adequate $\mathrm{S}$ nutrition has regulatory interactions with $\mathrm{N}$ assimilation and also can enhance the photosynthesis process Scherer. ${ }^{89} \mathrm{~S}$ is an important constituent for $\mathrm{N}$ assimilation, protein and co-enzymes synthesis. The results obtained by ${ }^{90,91}$ revealed that the application of humic and SWE may be increased the uptake of mineral elements. Many study supported these results such as Ameri and Tehranifar ${ }^{75}$ on Fragaria ananasa L, and Boghdady et al. ${ }^{92}$ on chickpea seeds.

Ayas and Gulser ${ }^{93}$ showed the application of humic acid at rate of $(250 \mathrm{~g})$ on spinach led to increase nutrient content, amino acid and sugars concentration. On the other hand after the storage intervals, the respiration rate increase as well as $\mathrm{S}$ content and the total amount of protein decreased.

Potassium $(\mathrm{K})$ is one of the essential elements of a plant that has a positive role in biosynthesis of vitamins, proteins and metabolism of nucleic acids ${ }^{94,95}$ Furthermore, Potassium is an important nutrient involved in transpiration, stomatel opening, osmoregulation, photosynthesis and enzymes activation. ${ }^{96,97}$ Also K participated in critical physiological processes such as transport of food so phloem, osmotic potential of cells as well as cell extension wall. ${ }^{98-101}$ showed that antioxidants applied on leaves led to significantly increased in potassium concentration in cucumber and tomato plants. The application of antioxidants as a foliar spray on leaves increased nutrients uptake of the soil helped to form the roots and reach the appropriate size of the harvest that reflected on the storage intervals that maintained the roots from oxidation processes and enzymatic browning. ${ }^{102}$ Similar results were also reported on sweet potato by EL-Sayed Hameda et al. ${ }^{103}$ on Allium sativum L. by Abd EL-Razzak and EL-Sharkawy, ${ }^{104}$ on radish plants by Ayub et al. ${ }^{105-107}$ On Spinacia oleraceae plants by Pirthiviraj et al.

\section{Acknowledgments}

None.

\section{Conflicts of interest}

Authors declare that there is no conflict of interest.

\section{References}

1. Paredes SD. Etnobotánica Mexicana: Plantas popularmente empleadas en el Estado de Michocán en el tratamiento de enfermedades hepaticas y vesiculares. Tesis Lic, México DF. Facultad de Ciencias. 1984.

2. Ku KH, Lee KA, Kim YE. Physiological activity of extracts from radish (Raphanus sativus L.) leaves. Journal of the Korean Society of Food science and nutrition. 2008;37:390-395.

3. Cho EH, Choi AR, Choi SJ, et al. $\alpha$-Amylase activity of radish and stability in processing. J Korean Soci of Food sci and nutri. 2009;38:812-815.

4. Gutiérrez RMP, Perez RL. Raphanus sativus (Radish): their chemistry and biology. The scientific world journal. (2004);4: 811-837.

5. Kapoor LD. Handbook of ayurvedic medicinal plants. CRC Press. Boca Raton. 2000;1:424.
6. Hwang JW, Kim EK, Lee SJ, et al. Anthocyanin effectively scavenges free radicals and protects retinal cells from $\mathrm{H} 2 \mathrm{O} 2$-triggered $\mathrm{G} 2 / \mathrm{M}$ arrest. Eur Food Res Technol. 2011;234:431-439.

7. Kader AA. Postharvest technology of horticultural crops. 3rd ed. Ethiop J Appl Sci Technol. 2002;3311.

8. Senesi N, Miano TM, Brunetti G. Humic-like substances in organic amendments and effects on native soil humic substances. In: Piccolo A. editor. Humic Substances in Terrestrial Ecosystems. USA, New York: 1996.

9. Karakurt Y, Unlu H, Padem H. The influence of foliar and soil fertilization of humic acid on yield and quality of pepper. Acta Agriculturae Scandinavica Section B Plant Soil Science. 2009;59(3):233-237.

10. Boehme M, Schevtschenko J, Pinker I. Iron supply of cucumbers in substrate culture with humate. Acta Hort. 2005;41(1):329-335.

11. Nardia S, Pizzeghelloa D, Muscolob A, et al. Physiological effects of humic substances on higher plants. Soil Biology \& Biochemistry. 2002;34:1527-1536.

12. Ordog V, Stirk WA, van Staden J, et al. Endogenous cytokinins in the three genera of microalgae from the Chlorophyta. J Phycol. 2004;40:8895 .

13. Kasim WA, Hamada EAM, Shams El-Din, et al. Influence of seaweed extracts on the growth, some metabolic activities and yield of wheat grown under drought stress. Int J Agri \& Agri Res. 2015;7(2):173-189.

14. Justesen U, Knuthsen P. Composition of flavonoids in fresh herbs and calculation of flavonoid intake by use of herbs in traditional Danish dishes. Food Chem. 2001;73:245-250.

15. Porte A, Godoy R. Chemical composition of thymus vulgaris L.(thyme) essential oil from the Rio de Janero state (Brazil). J Serb Chem Soc. 2008;73:307-310.

16. Nguefack J, Somda I, Mortensen CN, et al. Evaluation of five essential oils from aromatic plants of cameroon for controlling seed-borne bacteria of rice (Oryza sativa L.). Seed Sci \& Technol. 2005;33:397-407.

17. Black CA. Methods of soil analysis, American society of Agronomy, Inc. Wisconsin, USA. 1965.

18. Guenter E. The essential oils (Vol. III). New York: Van Nostrand. 1965.

19. Chiriboga CD, Francis FJ. Anthocyanins as food colors. J Food Sci. 1973;38:464-467.

20. Bray HG, Thorp WV. Analysis of phenolic compounds of interest in metabolism. Meth Biochem Anal. 1954;1:27-52.

21. Heimler D, Vignolini P, Dini, et al. Antiradical activity and polyphenol composition of local Brassicaceae edible varieties. Food Chem. 2005;99:464-469.

22. Freed M. The determination of total vitamin C. In: M Freed, editor Methods of vitamin assay. The Association of Vitamin Chemists. New York: Interscience; 1966. 320321p.

23. Dubois M, Gilles KA, Hamilton JK, et al. Colorimetric method for determination of sugars and related substances, Analyt Chem. 1956;28(3):350-356.

24. Moore S, Stein WH. Methods in Enzymol. In: Colowick SP, Kaplan ND, editors, Acad Pre. New York; 1984;3:468.

25. Maxwell DP, Beteman DF. Changes in the activities of some oxidases in extracts of Rhizoctonia. Phytopath. 1967;57:132.

26. Maria A, Galeazzi M, Valdemo $\mathrm{C}$, et al. Isolation, purification and physicochemical of polyphenol oxidase (PPO) from adwarf variety of banana. $J$ of food Sc. 1981;46:150-155. 
27. El-Mougy S, Abdel-Kader M, Aly H. Effect of a new chemical formula on postharvest decay incidence in citrus Fruit. $J$ Plant Protect Res. 2012;52(1):156-164

28. Lee SK. A review and background of the avocado maturity standard. Calif. Avocado Soc. Yearbook; 1981;65:101-109.

29. Gomez KH, Gomez AA. Statistical procedures for agriculture research. John Willy and Sons Inc. New York; 1984.

30. Evans JD. Straightforward statistics for the behavioural sciences. Pacific Grove, CA: Brooks/Cole Publishing; 1986.

31. Bayoumi Y. Improvement of postharvest keeping quality of white pepper fruits (Capsicum annuum L.) by hydrogen peroxide treatment under storage conditions. Acta Biolo Szege. 2008;52:7-15

32. Jackson PJ, Harker FR. Changes in firmness of the outer pericarp, inner pericarp, and core of actinidia species during ripening. New Zealand. J Crop Hort Sci. 1997;25:185-189.

33. Javanmardi J, Kubota C. Variation of lycopene, antioxidant activity, tota soluble solid and weight loss of tomato during postharvest storage. Post Biol Technol. 2006;41:151-155.

34. Shen Y, Sun Y, Qiao L, et al. Effect of UV-C treatments on phenolic compounds and antioxidant capacity of minimally processed Satsuma mandarin during refrigerated storage. J Postharvest Biol Technol. 2013;76:50-57.

35. Scholz B. Atmungsverluste bei weizen in abhangigkeit von temperature, lagerzeit und wassergehalt. landtechn forschung. 1962;12(2):48-52.

36. Kittock DL, Law AG. Relationship of seedling vigor to respiration and tetrazolium reduction in germinating wheat seeds. Agrono J. 1968;60:268-288.

37. Porter KL, Klieber A, Collins G. Chilling injury limits low temperature storage of Yuki 'Chinese cabbage. Post BioTechn. 2003;28:153-158.

38. Isman MB. Plant essential oils for pest and disease management. Crop Prot. 2000;19:603-608.

39. Bakkali F, Averbeck S, Averbeck D, et al. Biological effects of essential oils areview. Food and Chemical Toxicology. 2008;46:446-475.

40. Burt S. Essential oils: their antibacterial properties and potential applications in foods-a review. Int J Food Microbiol. 2004;94:223-253.

41. Dew MJ, Evans JR. Peppermint oil for the irritable bowel syndrome; a multi center trialm. Br J Clin Pract. 1984;38:394-395.

42. Dew MJ, Evans BK, Rhodes J. Peppermint oil for the irritable bowel syndrome: a multicentre trial. Br J Clin Pract. 1984;38(1112):394-398.

43. Aminifard MH, Mohammadi S. Essential oils to control botrytis cinerea in vitro and in vivo on plum fruits. Journal of the Science of Food and Agriculture. 2013;93(2):348-353

44. Janparvar F, Aboutalebi A, Abdossi V, et al. Study on the antifunga effect of mint extracts on postharvest life of navel orange and comparison its effect with Karbandazim fungicide. Intl J Farm \& Alli Sci. 2014;3(12):1332-1334.

45. Alikhani M, Sharifani M, Mousavizade SJ, et al. Increasing shelf life and maintaining quality of strawberries (Fragaria ananassa L.) with application of mucilage edible coating and plant essential oil. J Agric Sci Nat Resour. 2009;16(2):1-10.

46. Geransayeh M, Sepahvand S, Abdossi V, et al. Effect of thymol treatment on decay, postharvest life and quality of strawberry (Fragaria ananassa) Fruit cv. Gaviota. Inter J Agro and Agri Res. (IJAAR). 2015;6(4):151162.
47. Sahar M, Abd El wahab. Maintain postharvest quality of nectarine fruits by using some essential oils. Middle East J Appl Sci. 2015;5(4):855-868.

48. Amin A. Determination of some essential oils effects on the quality traits of the egyptian anna apple fruit during its shelf life. Horti Sci \& Ornam Plants. 2016;8(1):35-45.

49. Hounsome N, Hounsome B, Tomos D, et al. Changes in antioxidant compounds in white cabbage during winter storage. Post Biolo Technol. 2009;52:173-179.

50. Tavarini S, Degl IE, Remorini D, et al. Antioxidant capacity, ascorbic acid, total phenols and carotenoids changes during harvest and after storage of Hayward kiwifruit. Food Chemistry. 2008;107:282-288.

51. Koh E, Wimalasiri KMS, Chassy AW, et al. Content of ascorbic acid, quercetin, kaempferol and total phenolics in commercial broccoli. Food Compos Anal. 2009;22:637-643.

52. Navarro J, Flores P, Garrido C, et al. Changes in the contents of antioxidant compounds in pepper fruits at different ripening stages, as affected by salinity. Food Chem. 2006;96:66-73.

53. Wang CY, Wang SY, Chen C. Increasing antioxidant activity and reducing decay of blueberries by essential oils. J Agri and Food Chem. 2008;56:3587-3592.

54. Žnidarcici D, Pozri T. Comparative study of quality changes in tomato cv. 'Malike' (Lycopersicon esculentum Mill.) whilst stored at different temperatures. Acta Agri Slovenica. 2006;87-2.

55. Del Nobile MA, Licciardello F, Scrocco C, et al. Design of plastic packages for minimally processed fruits. J Food Engi. 2007;79:217-224

56. Kramchote S, V. Srilaong V, Wongs-Aree C, et al. Low temperature storage maintains postharvest quality of cabbage (Brassica oleraceae var. capitata L.) in supply chain. Inter Food Res J. 2012;19(2):759-763.

57. Di F, Kandasamy S, Mark Hodges D, Alan TC, et al. Pre-harvest treatment of spinach with Ascophyllum nodosum extractimproves postharvest storage and quality. Scientia Horticulturae. 2014;170:70-74.

58. Timberlake CF. Anthocyanins in fruit and vegetables. In: J Friend, MJC Rhodes, editors, Recent advances in the biochemistry of fruit and vegetables. New York: Academic Press. 1981;221-247.

59. Yamasaki H, Uefuji H, Sakihama Y. Bleaching of the red anthocyanin induced by superoxide radical. Arch Biochem Biophys. 1996;332(1):183186.

60. Leng P, Qi JX. Effect of anthocyanin on david peach (Prunus davidiana Franch) under low temperature stress. Scien Horti. 2003;97:27-39.

61. Hubbermann EM, Heins A, Stockmann H, et al. Influence of acids, salt, sugars and hydrocolloids on the colour stability of anthocyaninrich blackcurrant and elderberry concentrates. Eur Food Res Technol. 2006;223:83-90

62. Lo'pez-Andreu FJ, Molla E, Fernandez M, et al. Conservacio' n en fri'o de berenjenas. Modificaciones de sucalidad. Alimentaria. 1988;31:32-36.

63. Hodges DM, Forney CF. The effects of ethylene, depressed oxygen and elevated carbon dioxide on antioxidant profiles of senescing spinach leaves. J Exp Bot. 2000;51:645-655.

64. Foyer $\mathrm{CH}$, Noctor G. Ascorbate and glutathione: the heart of the redox hub. Plant Physiol. 2011;155:2-18.

65. Emese J, Nagymate PF. The stability of vitamin C in different beverages. Brit Food J. 2008;110(3):296-309.

66. Ajibola VO, Babatunde OA, Suleiman S. The effect of storage method on the vitamin $\mathrm{C}$ content in some tropical fruit juices. Tr App Sci Res. 2009;4(2):79-84. 
67. Lee SK, Kader AA. Preharvest and postharvest factors influencing vitamin C content of horticultural crops. Post Biol Techn. 2000;20(3):207-220.

68. Serrano M, Martinez-Romero D, Castillo S, et al. The use of natural antifungal compounds improves the beneficial effect of MAP in sweet cherry storage. Inn Food and Sci Emer Techn. 2005;6(1):115-123.

69. Raafat SM, Abou-Zaid MI, Aly AZ, et al. Safety control of strawberry fruits gray mold fungus by plant volatile oils. Zagazig J Agri Res. 2012;39(2):181-187.

70. Yang Y, Wang J, Xing Z, et al. Identification of phenolics in Chinese toon and analysis of their content changes during storage. Food Chem. 2011;128:831-838

71. Toor RK, Savage GP. Changes in major antioxidant components of tomatoes during post-harvest storage. Food Chem. 2006;39: 724-727.

72. Dupont MS, Mondin Z, Williamson G, et al. Effect of variety ,processing and storage on the flavonoid glycoside content and composition of lettuce and endive. Agri Food Chem. 2000;48:3957-3964.

73. Yuan G, Sun B, Yuan J, et al. Effect of 1-methylecyclopropene on shelf life visual quality, antioxidant enzymes and health promoting compounds in broccoli florets. Food Chem. 2010;118:774-781.

74. Bakry BA, Elewa TA, El-Kramany M, et al. Effect of humic and ascorbic acids foliar application on yield and yield components of two wheat cultivars grown under newly reclaimed sandy soil. Intl Journal of Agron of Plant Production. 2013;4(6):1125-1133.

75. Ameri A, Tehranifar A. Effect of humic acid on nutrient uptake and physiological characteristic Fragaria ananasa var: Camarosa. J Biol Environ Sci. 2012;6(16):77-79.

76. Paul JP, Mahadevi B. Effect of seaweed liquid fertilizer of caulerpa peltata Lamour (Green seaweed) on vigna radiate (L.)R. Wilczek.., Idinthakarai, tamil nadu, India .World Journal of Pharma Cuti Sci. 2014;3(6):1000-1007.

77. Wills HHR, Lee TH, Graham D, et al. An introduction to the physiology and handling of fruits and vegetables. New South Wales University Press Limited. Australia; 1988.

78. Qualls R, Haines BL. Geochemistry of dissolved organic nutrients in water percolating through a forest ecosystem. Soil Sci Soc Am J. $1991 ; 55: 1112-1123$

79. Yu Z, Zhang Q, Kraus TEC. Contribution of amino compounds to dissolved organic nitrogen in forest soils. Biogeochemistry. 2002;61:173198

80. Lipson DA, Nasholm T. The unexpected versatility of plants: organic nitrogen use and availability in terrestrial ecosystems. Oecologia. 2001; 128:305-316.

81. Beevers L. Nitrogen metabolism in plants. Biology of Inorganic Nitrogen and Sulfr. 1976;58-65.

82. Lewis EJ, Gonzalves Ella A. The protein peptide and free amino acid of some species of marine algae from Bombay. Ann J Bot. 1962;26:301316.

83. Kalidass C, Jayarani S, Glory M. Effect of seaweed liquid fertilizer on growth and biochemical constituents of Brassica nigra Linn. $I J A F B$. 2010;3(3):307-311.

84. Gzik A. Accumulation of proline and pattern of -amino acids in sugar beet plants in response to osmotic, water and salt stress. Environ Experi Bot. 1996;36(1):29-38.

85. Pareek S, Benkeblia N, Janick J, et al. Postharvest physiology and technology of loquat (Eriobotrya japonica Lindl.) fruit. J Sci Food Agric. 2014;94(8):1495-504.
86. Osman Ash, Rady MM. Ameliorative effects of sulphur and humic acid on the growth, anti-oxidant levels and yields of and pea (Pisum sativum L.) plants grown in reclaimed saline soil. J Hort Sci Biotechnol. 2012;87:626-632.

87. Lunde C, Zygadko A, Simonsen HT, et al. Sulphur starvation in rice: the effect on photosynthesis, carbohydrate metabolism, and oxidative stress protective pathways. Physiol Plant. 2008;134:508-521.

88. Hawkesford MJ. Plant responses to sulphur deficiency and the genetic manipulation of sulphate transporters to improve S-utilization efficiency. J Exp Bot. 2000;51(342):131-138.

89. Scherer HW. Impact of sulphur on N2 fixation of legumes. In: sulphur assimilation and abiotic stresses in plants. In: Khan NA, Singh S, editors, Springer-Verlag, New York; 2008;43-54.

90. De Kreij C, H Basar. Effect of humic substances in nutrient film technique on nutrient uptake. J Plant Nutr. 1995;18:793-802.

91. Mackowiak CL, Grossl PR, Bugbee BG. Beneficial effects of humic acid on micronutrient availability to wheat. Soil Sci Soc Am J. 2001;56:17441750

92. Boghdady MS, Dalia AH, Selim, et al. Influence of foliar spray with seaweed extract on growth, yield and its quality, profile of protein pattern and anatomical structure of chickpea plant (Cicer arientium L.,). Middle East J Appl Sci. 2016;6(1):207-221.

93. Ayas H, Gulser F. The effects of sulfur and humic acid on yield components and macronutrient contents of spinach. J Biol Sci. 2005;5(6):801-804.

94. Bisson P, Cretenet M, Jallas E. Nitrogen, phosphorus and potassium availability in the soil physiology of the assimilation and use of these nutrients by the plant, challenging the future: proceedings of the world cotton research conference, Brisbane Australia, 17th ed. Constable GA. NW Forrester, CSIRO, Melbourne; 1994;115-124.

95. Bednarz CW, Oosterhuis DM. Physiological changes associated with potassium deficiency in cotton. J Plant Nutr. 1999;22:303-313.

96. Cakmak I. The role of potassium in alleviating detrimental effects of abiotic stresses in plants. J Plant Nutr Soil Sci. 2005;168: 521-530.

97. Millfrod GF, Johnston AE. Potassium and nitrogen interactions in crop production. Inter Ferti Soci. UK; 2002.

98. Guler S, Ibrikci H. Yield and elemental composition of cucumber as affected by drip and furrow irrigation. Acta Hortic. 2002; 571:51-57.

99. Cherel L. Regulation of $\mathrm{K}+$ channel activities in plants: From physiological to molecular aspects. J Exp Bot. 2004;55:337-351.

100. Al-Karaki GN. Growth, sodium and potassium uptake and translocation in salt stressed tomato. J Plant Nutr. 2000;23: 369-379.

101. Watcharasak S, Thammasak T. Effect of nitrogen and potassium concentration in fertigation on growth and yield of cucumber Kamphaengsaen Acad J. 2005;3:18-29.

102. Bombelli EC, Wright ER. Tomato fruit quality conservation during postharvest by application of potassium bicarbonate and its effect on Botrytis cinerea. Cien Inv Agric. 2006;33:167-172.

103. El Sayed Hameda EA, Saif El Dean A, Ezzat S, et al. Responses of productivity and quality of sweet potato to phosphorus fertilizer rates and application methods of the humic acid. Intern Res J Agri Sci Soil. 2011;1:383-393.

104. AbdEl-Razzak HS, EL-Sharkawy GA. Effect of biofertilizer and humic acid applications on growth, yield, quality and storability of two garlic (Allium sativum L.,) cultivars. Asian J Crop Sci. 2013;5(1):48-64.

105. Ayub AR, Spinardi B, Gioppo M. Storage and fresh cut radish. Acta Sci Agro. 2013;35(2):241-245. 
106. Association of official analytical chemists (AOAC). Official methods of analysis of the association of official analytical chemists international. In: Horwitz W, editor, 17th ed. AOAC Press, Arlington, USA; 2007
107. WA Kasim, EAM Hamada, NGS El-Din, et al. Influence of seaweed extracts on the growth, some metabolic activities and yield of wheat grown under drought stress. Int J Agri \& Agri Res. 7(2):173-189. 